\title{
INOVASI TEKNOLOGI PADAT TEBAR AWAL TERHADAP KELANGSUNGAN HIDUP DAN PERTUMBUHAN BENIH PATIN HIBRID PASUPATI DALAM SISTEM RESIRKULASI
}

Technology Innovation of Early Stocking Density Survival and Growth

Patin Seeds in Hybrid Pasupati a Recirculation System

\author{
Yudha Lestira Dhewantara \\ JL. Arteri Pondok Indah No 11 Jakarta Selatan, \\ Universitas Satya Negara Indonesia (USNI), 12240 \\ Email : yudhalestira@gmail.com
}

\begin{abstract}
Abstrak
Penelitian ini bertujuan untuk mengetahui padat tebar awal yang optimal dalam sistem resirkulasi yang dapat menghasilkan kelangsungan hidup dan pertumbuhan larva patin pasupati tertinggi. Tingkat kepadatan larva patin pasupati yang diuji dalam penelitian ini adalah 20 ekor/L, 40 ekor/L, 60 ekor/L, 80 ekor/L dan 100 ekor/L. Larva patin hibrid pasupati dipelihara selama 42 hari dalam bak fiber berukuran $57 \mathrm{~cm}$ x 36 $\mathrm{cm}$ x $29 \mathrm{~cm}$ yang dilengkapi dengan sistem resirkulasi dan diisi air sebanyak $30 \mathrm{~L}$. Rancangan percobaan yang digunakan adalah Rancangan Acak Lengkap dengan 5 perlakuan dan 3 ulangan. Parameter yang diamati adalah kelangsungan hidup, pertumbuhan panjang mutlak dan pertumbuhan berat mutlak. Hasil penelitian menunjukkan bahwa padat penebaran awal 20 ekor/L, 40 ekor/L, 60 ekor/L, 80 ekor/L dan 100 ekor/L menunjukkan perbedaan pada kelangsungan hidup, pertumbuhan panjang mutlak dan pertumbuhan berat mutlak. Padat penebaran awal yang terbaik adalah padat penebaran 40 ekor/L dengan kelangsungan hidup sebesar $66,14 \%$, pertumbuhan panjang mutlak $5,03 \mathrm{~cm}$ dan pertumbuhan bobot mutlak 2,05 gram. Padat penebaran tertinggi (100 ekor/L) masih menghasilkan kelangsungan hidup, pertumbuhan panjang mutlak dan pertumbuhan bobot mutlak yang tidak berbeda dengan padat penebaran 60 ekor/L.
\end{abstract}

Kata kunci : sistem resirkulasi, benih patin pasupati, padat tebar

\begin{abstract}
The aim of this research was to find out the optimum initial stocking density in recirculation system that resulted the highest survival rate and growth rates of pasupati hybrid patin larvae. Larvae density levels of pasupati hybrid patin examined in the research were 20 larvae/L, 40 larvae/L, 60 larvae/l, 80 larvae/L and 100 larvae/L. Pasupati hybrid patin larvae were grown during 42 days in fiber container $57 \mathrm{~cm}$ x 36 $\mathrm{cm} \times 29 \mathrm{~cm}$ equipped with recirculation system and filled with water of $30 \mathrm{~L}$. Design of the experimental used was Completely Randomized Design with five treatments and three repetitions. Parameters observed were survival rate, absolutely body length growth and absolutely body weight growth. The result of this research showed that initial stocking density of 20 larvae/L, 40 larvae/L, 60 larvae/l, 80 larvae/L and 100 larvae/L was providing significant difference on survival rate, absolutely body length growth and absolutelv body weight growth. The optimum of initial stosking density was 40 larvae/L
\end{abstract}


with survival rate value $66,14 \%$, absolutely body length growth $5,03 \mathrm{~cm}$ and absolutely body weight growth 2,05 gram. The highest of initial stosking density (100 larvae/L) still showed survival rate, absolutely body length growth and absolute body weight growth did not cause significant difference 60 larvae/L.

Keywords: recirculation system, Pasupati catfish seed, stock density

\section{Latar Belakang}

\section{PENDAHULUAN}

Patin Pasupati (Patin Super Harapan Pertiwi) adalah ikan hasil persilangan antara patin siam betina dengan patin jambal jantan. Ikan ini mempunyai beberapa keunggulan dibandingkan patin lainnya yaitu warna dagingnya putih dan teksturnya lembut dengan kadar lemak rendah, pertumbuhan relatif cepat, fekunditas telurnya tinggi dan produksi larva dapat diproduksi secara massal sehingga diharapkan dapat memenuhi kebutuhan larva patin daging putih dalam jumlah besar untuk memenuhi kebutuhan ekspor yang sebelumnya tidak dapat dipenuhi. Departemen Kelautan dan Perikanan menargetkan produksi perikanan budidaya dengan salah satu komoditas unggulannya adalah patin daging putih pada tahun 2014 sebanyak 25.7000.000 ton (Dahuri, 2010). Untuk menunjang produksi yang optimal dan berkesinambungan maka diperlukan penyediaan larva secara kualitas dan kuantitas.

Sebagai komoditas budidaya yang relatif baru, untuk meningkatkan produksi larva maka perlu diupayakan suatu teknologi budidaya yang memungkinkan ikan dapat dipelihara dengan kepadatan tinggi dan kualitas media yang terkontrol. Mengantisipasi hal tersebut maka perlu dicari kepadatan larva optimal yang dapat menghasilkan produksi yang maksimal melalui upaya budidaya yang dilakukan secara intensif

Padat penebaran yang tinggi akan mengakibatkan terjadinya kompetisi dalam mendapatkan pakan serta ruang gerak sehingga dapat mengakibatkan perbedaan variasi pertumbuhan. Selain itu, kepadatan yang tinggi akan mempengaruhi kualitas air. Hal ini disebabkan karena sering terjadi penumpukan bahan organik yang berasal dari buangan sisa metabolisme ikan dan sisa pakan yang tidak termakan. Kepadatan yang tinggi juga menyebabkan berkurangnya kandungan oksigen terlarut yang disebabkan konsumsi oksigen oleh ikan dan proses dekomposisi bahan organik.

Sistem resirkulasi adalah suatu sistem produksi yang menggunakan air lebih dari satu kali setelah melalui proses pengolahan limbah dan adanya sirkulasi air atau perputaran air (Losordo, 1988). Pada sistem resirkulasi padat penebaran dapat ditingkatkan karena adanya pengontrolan terhadap perbaikan lingkungan yang dilakukan secara kontinyu serta penyediaan oksigen terlarut dapat terjamin (Landau, 1992). Pemeliharaan larva patin pasupati dengan padat penebaran yang tinggi dan didukung dengan kondisi kualitas air yang terjaga pada suatu sistem resirkulasi diharapkan akan meningkatkan jumlah produksi larva patin pasupati.

Penelitian ini bertujuan untuk mengetahui padat penebaran awal yang optimum dalam sistem resirkulasi yang dapat menghasilkan kelangsungan hidup dan pertumbuhan larva patin hibrid pasupati tertinggi. 
Tahap pemeliharaan larva merupakan salah satu kendala yang sering dihadapi para pembudidaya dalam usaha peningkatan produksi benih karena pada tahap ini merupakan massa kritis bagi larva yang rentan terhadap kondisi lingkungan dan sering menyebabkan kematian. Secara umum, pemeliharaan larva sampai dengan umur 30 hari atau benih berukuran \pm 1 inchi hanya menghasilkan kelangsungan hidup sekitar $10-30$ \% (Hardjamulia at al., 1988). Rendahnya nilai kelangsungan hidup ini diduga karena kebutuhan hidup larva yang meliputi pakan dan lingkungan optimal belum terpenuhi. Selain itu pada sistem budidaya intensif, menerapkan padat penebaran yang tinggi. Semakin tinggi padat penebaran maka semakin sempit pula ruang geraknya. Hal ini dapat menyebabkan hambatan pada perkembangan larva itu sendiri karena terjadi persaingan atau kompetisi antara sesama larva dalam hal ruang gerak, pakan dan konsumsi oksigen.

Pemeliharaan larva dengan kepadatan tinggi selalu disertai dengan tingginya jumlah pemberian pakan. Semakin padat ikan yang dipelihara maka semakin banyak pula pakan yang diberikan dan memungkinkan sisa pakan yang tidak termakan menjadi lebih banyak juga buangan metabolismenya semakin tinggi. Kondisi ini menyebabkan menurunnya kualitas air media pemeliharaan, sedangkan larva sangat sensitif terhadap perubahan kualitas air media pemeliharaan.

Pada penelitian Esti (2010) terhadap larva patin pasupati berumur 1 hari yang dipelihara dalam sistem non resirkulasi dengan perlakuan padat tebar 25, 50, 75 dan 100 ekor/liter menunjukkan tingkat kelangsungan hidup 70,67\%, 62,07\%, 58,90\% dan $45,80 \%$. Pertumbuhan panjang berkisar antara $3,22 \mathrm{~cm}$ hingga $4,99 \mathrm{~cm}$. Pada penelitian tersebut kualitas air terlihat tidak stabil dimana ammonia dan nitrit melebihi batas toleransi yang disarankan. Penelitian tersebut memperlihatkan bahwa kelangsungan hidup dan pertumbuhan panjang masih dapat ditingkatkan apabila dipelihara dalam sistem resirkulasi karena kualitas air media pemeliharaan dapat dipertahankan.

Pada penelitian Ariyanto et.al, (2008) terhadap larva patin siam berumur 1 hari yang dipelihara dalam sistem resirkulasi dengan perlakuan padat tebar yang tinggi yaitu 50, 100 dan 150 ekor/liter menunjukkan tingkat kelangsungan hidup yang rendah yaitu berkisar antara 22,79-34,74\%. Hasil analisis penelitian tersebut menunjukkan bahwa padat tebar 50 ekor/liter efektif dilakukan sampai dengan hari ke 30.

Pada penelitian Hidayat (2007) terhadap benih patin siam berumur 3 minggu yang dipelihara selama 30 hari dengan perlakuan padat tebar 15, 30, 45 dan 60 ekor/liter masing-masing menghasilkan kelangsungan hidup sebesar 99,55\%, 99,39\%, 98,99\% dan $91,86 \%$. Pertumbuhan panjang berkisar antara $3,54 \mathrm{~cm}$ hingga $3,64 \mathrm{~cm}$.

\section{METODOLOGI PENELITIAN}

\section{Tempat dan Waktu Penelitian}

Penelitian ini dilaksanakan di hatchery Balai Penelitian Pemuliaan Ikan (BPPI) Sukamandi. Balai ini berlokasi di Jalan Raya No.2 Sukamandi - Subang Jawa Barat.

Penelitian berlangsung selama 3 (tiga) bulan yaitu dari bulan Juni 2015 hingga Agustus 2015. Persiapan penelitian dilakukan selama 7 hari dan pelaksanaan penelitian yaitu pemeliharaan larva dilakukan selama 42 hari. 


\section{Metode Penelitian}

Metode penelitian yang digunakan adalah metode eksperimental, menggunakan Rancangan Acak Lengkap yang terdiri atas 5 perlakuan dan 3 ulangan. Perlakuannya adalah perbedaan padat penebaran awal, yaitu :

1. Perlakuan A : kepadatan 20 ekor/L

2. Perlakuan B : kepadatan 40 ekor/L

3. Perlakuan $\mathrm{C}$ : kepadatan 60 ekor/L

4. Perlakuan D : kepadatan 80 ekor/L

5. Perlakuan E : kepadatan 100 ekor/L

\section{Prosedur Penelitian}

\section{Pelaksanaan Penelitian}

- Menghitung larva patin pasupati sesuai perlakuan padat penebaran dan dimasukan pada masing-masing bak.

- Mengambil larva patin pasupati pada setiap bak sebanyak 30 ekor untuk diukur panjang dan berat pada awal penelitian.

- Memberikan pakan secara add libitum selama pemeliharaan. Jenis pakan yang diberikan dan frekuensi pemberian pakan selama penelitian dapat dilihat pada Tabel 1 berikut ini.

Tabel 1. Jenis Pakan dan Frekuensi Pemberian Pakan Selama Penelitian

\begin{tabular}{|c|c|}
\hline Jenis Pakan & Frekuensi \\
\hline a. Naupli artemia & 2 jam sekali pada hari pertama hingga hari ke 2 \\
\hline \multirow{5}{*}{$\begin{array}{l}\text { b. Cacing tubifex } \\
\text { c. Pellet crumble ukuran } \\
0,425 \text { x } 0,71 \mathrm{~mm} \\
\text { d. Pellet crumble ukuran } \\
0,71 \times 1 \mathrm{~mm}\end{array}$} & 3 jam sekali pada hari ke 3 hingga hari ke 5 \\
\hline & 3 jam sekali pada hari ke 6 hingga hari ke 12 \\
\hline & 3 jam sekali pada hari ke 13 hingga hari ke 18 \\
\hline & \\
\hline & $\begin{array}{l}3 \text { jam sekali pada hari ke } 19 \text { hingga hari ke } 27 \text { dan } \\
6 \text { kali sehari pada hari ke } 28 \text { hingga hari ke } 42\end{array}$ \\
\hline
\end{tabular}

\section{Parameter Penelitian}

\section{A. Kelangsungan Hidup}

Kelangsungan hidup larva patin hibrid pasupati dihitung dengan menggunakan persamaan sebagai berikut (Effendie, 1997) : 


$$
\begin{gathered}
\mathrm{SR}=\underline{\mathrm{N}_{\mathrm{t}}} \mathbf{X} 100 \% \\
\text { No }
\end{gathered}
$$

Keterangan :

$\mathrm{SR}=$ Kelangsungan hidup $(\%)$

$\mathrm{N}_{\mathrm{t}}$ = Jumlah ikan pada akhir pengamatan (ekor)

$\mathrm{N}_{0}=$ Jumlah ikan pada awal pengamatan (ekor)

\section{B. Pertumbuhan Panjang}

Pengukuran pertumbuhan panjang tubuh larva patin hibrid pasupati dilakukan dengan cara mengukur panjang larva pada awal penelitian dan dilakukan setiap seminggu sekali selama penelitian. Perhitungan pertumbuhan panjang mutlak dilakukan dengan menggunakan persamaan sebagai berikut (Effendie, 1997) :

$$
\mathrm{L}=\mathrm{L}_{\mathrm{t}}-\mathrm{Lo}
$$

Keterangan :

$\mathrm{L}=$ Pertumbuhan panjang mutlak

$\mathrm{L}_{\mathrm{t}}=$ Panjang rata-rata ikan pada waktu $\mathrm{t}(\mathrm{mm})$

Lo $=$ Panjang rata-rata ikan pada awal penelitian $(\mathrm{mm})$

\section{Pertumbuhan Bobot}

Pertumbuhan bobot larva patin hibrid pasupati dilakukan dengan cara menimbang lava patin pada awal penelitian dan dilakukan setiap seminggu sekali selama penelitian. Perhitungan pertumbuhan bobot dilakukan dengan menggunakan persamaan sebagai berikut (Effendie, 1997) :

$$
\mathrm{W}=\mathrm{Wt}-\mathrm{Wo}
$$

Keterangan :

$\mathrm{W}=$ Pertumbuhan bobot ikan (gram)

Wo $=$ Bobot ikan di awal penelitian (gram)

$\mathrm{Wt}=$ Bobot ikan pada waktu $\mathrm{t}(\mathrm{gram})$

\section{Kualitas Air}

Parameter kualitas air yang diamati dan alat yang digunakan serta frekuensi pengukuran dalam penelitian ini dapat dilihat pada Tabel 2. 
Tabel 2. Parameter Fisik-kimiawi Air yang Diukur, Alat yang Digunakan serta Frekuensi Pengukuran

\begin{tabular}{|l|l|l|}
\hline \multicolumn{1}{|c|}{ Parameter } & \multicolumn{1}{|c|}{ Alat } & \multicolumn{1}{c|}{ Frekuensi Pengukuran } \\
\hline Suhu $\left({ }^{\circ} \mathrm{C}\right)$ & Water Quality Checker & Setiap hari \\
\hline $\mathrm{pH}$ & Water Quality Checker & Seminggu sekali \\
\hline $\mathrm{DO}(\mathrm{mg} / \mathrm{l})$ & Water Quality Checker & Seminggu sekali \\
\hline Amoniak (mg/l) & Spektrofotometer & Seminggu sekali \\
\hline Nitrit $(\mathrm{mg} / \mathrm{l})$ & Spektrofotometer & Seminggu sekali \\
\hline
\end{tabular}

\section{Analisis Data}

Untuk mengetahui pengaruh perlakuan terhadap kelangsungan hidup dan pertumbuhan dilakukan analisis keragaman dengan uji-F dan apabila terdapat perbedaan antar perlakuan dilakukan dengan uji jarak berganda Duncan pada taraf kepercayaan 95\%. Analisis regresi digunakan untuk mengetahui hubungan antara padat penebaran terhadap kelangsungan hidup dan pertumbuhan.

\section{HASIL DAN PEMBAHASAN}

\section{HASIL}

\section{Kelangsungan Hidup Larva Patin Hibrid Pasupati}

Pengamatan terhadap kelangsungan hidup larva patin hibrid Pasupati selama penelitian (42 hari) dengan padat penebaran awal sebesar 20 ekor/L sampai 80 ekor/L menunjukkan bahwa perbedaan padat penebaran awal memberikan pengaruh terhadap kelangsungan hidup larva, makin besar padat penebaran makin rendah kelangsungan hidup larva (Gambar 1). Kelangsungan hidup larva hibrid Pasupati pada akhir penelitian berkisar antara 78,94\%-50,39\%. 


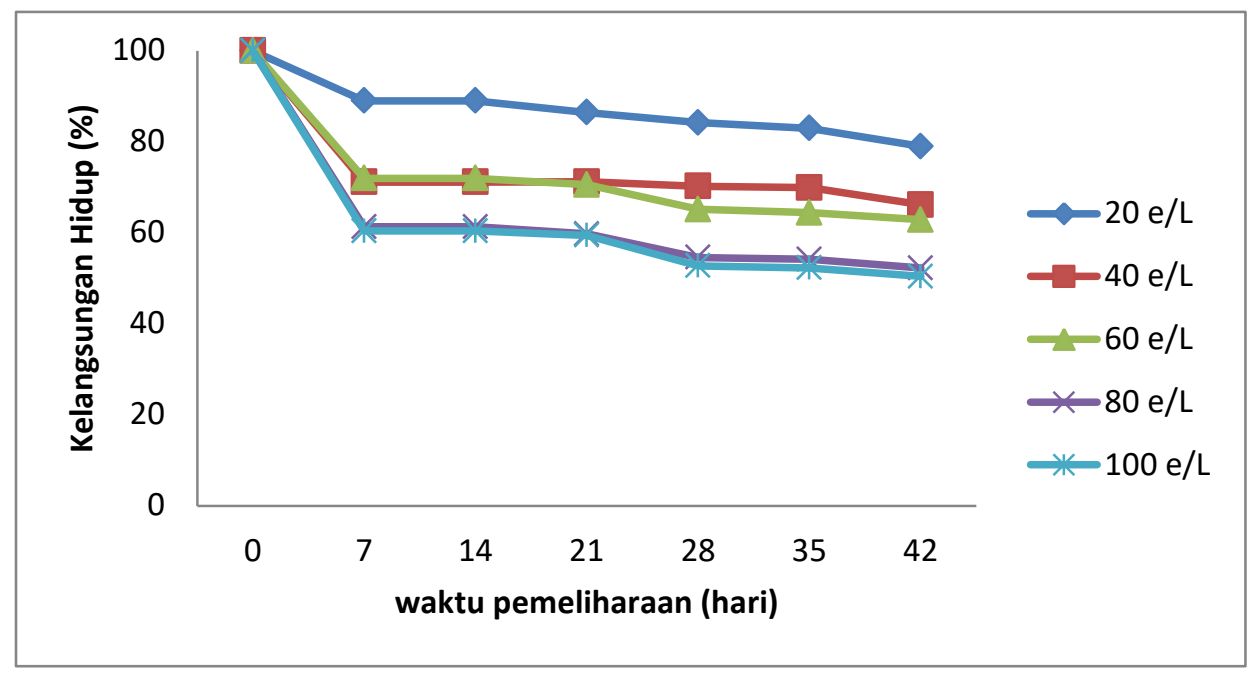

Gambar 1. Kelangsungan Hidup Larva Patin Hibrid Pasupati

\section{Selama Penelitian}

Kelangsungan hidup larva terendah didapatkan pada padat penebaran tertinggi (100 ekor/L) yang berbeda nyata dengan padat penebaran terendah (20 ekor/L), tetapi tidak berbeda nyata dengan padat penebaran 40 ekor/L, 60 ekor/L dan 80 ekor/L. Hal ini dikarenakan kompetisi diantara larva atau benih patin hibrid Pasupati dalam memperebutkan pakan dan ruang gerak lebih tinggi pada padat penebaran larva yang lebih tinggi. Ikan yang dipelihara dalam kepadatan yang tinggi akan lebih aktif untuk memperebutkan pakan dan oksigen sedangkan ruang geraknya semakin kecil sehingga larva atau benih lebih cepat mengalami stress yang akhirnya menyebabkan kematian. Stress yang terjadi menyebabkan eksresi sisa-sisa metabolisme menjadi lebih banyak dan menimbulkan peningkatan ammonia yang dapat menyebabkan kondisi toksisk bagi ikan.

\section{Pertumbuhan Panjang Mutlak Larva Patin Hibrid Pasupati}

Padat penebaran yang berbeda menghasilkan pertumbuhan panjang yang berbeda tiap periode. Panjang standard larva patin hibrid pasupati selama penelitian cenderung meningkat seiring dengan bertambahnya waktu pemeliharaan (Gambar 2). 


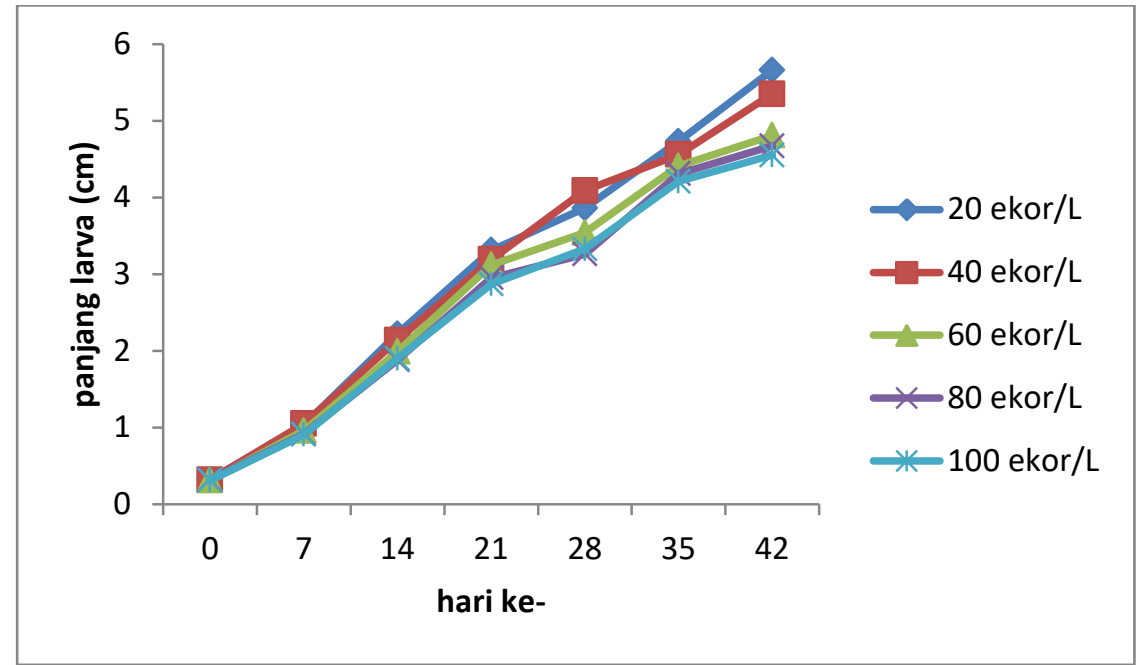

\section{Gambar 2. Pertambahan Panjang Larva Patin Hibrid Pasupati}

\section{Selama Penelitian}

Rata-rata panjang mutlak larva patin hibrid pasupati setelah pemeliharaan 42 hari pada padat penebaran awal 20 ekor/L -80 ekor/L berkisar antara $\quad 5,35-4,23$ $\mathrm{cm}$. Pada Gambar 2 terlihat bahwa panjang standar larva patin tertinggi pada padat penebaran 20 ekor/L dan terendah pada padat penebaran 100 ekor/L. Semakin tinggi padat penebaran, makin rendah pertumbuhan panjang standar larva patin hibrid pasupati. Hal ini menunjukkan bahwa makin tinggi kepadatan larva makin tinggi kompetisi diantara larva dalam memperebutkan pakan, oksigen dan ruang gerak.

\section{Pertumbuhan Bobot Mutlak Larva Patin Hibrid Pasupati}

Padat penebaran yang berbeda menghasilkan pertumbuhan bobot yang berbeda tiap periode. Pertambahan bobot larva patin hibrid pasupati selama penelitian cenderung meningkat seiring dengan bertambahnya waktu pemeliharaan (Gambar 3).

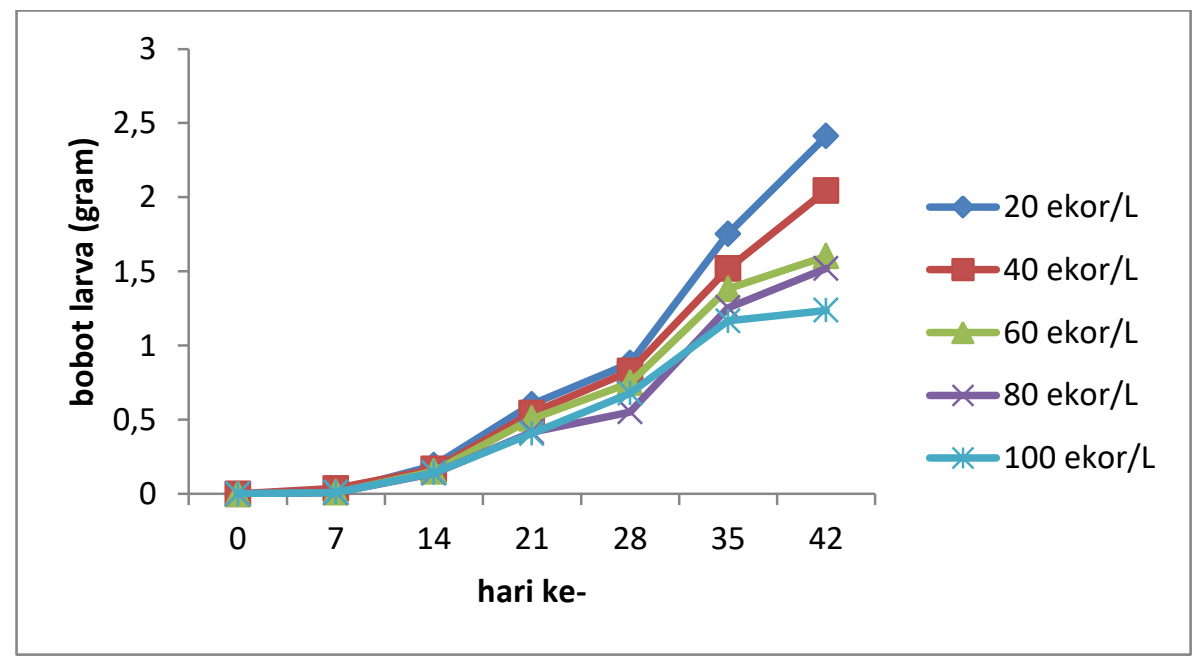

Gambar 3. Pertambahan Bobot Larva Patin Hibrid Pasupati

\section{Selama Penelitian}


Rata-rata bobot mutlak larva patin hibrid pasupati setelah pemeliharaan 42 hari pada padat penebaran awal 20 ekor/L -80 ekor/L berkisar antara 1,11 - 1,55 gram. Pada Gambar 3 terlihat bahwa bobot larva patin hibrid pasupati tertinggi pada padat penebaran 20 ekor/L dan terendah pada padat penebaran 100 ekor/L. Semakin tinggi padat penebaran,makin rendah pertumbuhan bobot larva patin hibrid pasupati. Hal ini menunjukkan bahwa makin tinggi kepadatan larva makin tinggi kompetisi diantara larva dalam memperebutkan pakan, oksigen dan ruang gerak. Pakan dalam pertumbuhan larva patin lebih banyak digunakan untuk pertumbuhan panjang dibandingkan untuk pertumbuhan bobot larva. Hal ini menunjukkan bahwa pertumbuhan bobot lebih lambat dibandingkan pertumbuhan panjang.

\section{Kualitas Air}

Dalam budidaya ikan, kualitas air merupakan salah satu faktor yang menentukan keberhasilan suatu usaha budidaya. Parameter kualitas air yang diamati selama penelitian meliputi suhu, oksigen terlarut (DO), derajat keasaman $(\mathrm{pH})$, amoniak dan nitrit. Hasil pengukuran kualitas air selama pemeliharaan masih dalam batas kelayakan bagi kehidupan larva patin hibrid pasupati (Tabel 3). Hasil penelitian yang telah dilakukan terlihat bahwa kualitas air pada masing-masing perlakuan mengalami penurunan dengan bertambahnya waktu pemeliharaan.

Tabel 3. Kisaran Nilai Kualitas Air Media Pemeliharaan Larva Patin Hibrid Pasupati Setiap Perlakuan Selama Penelitian.

\begin{tabular}{|c|c|c|c|c|c|}
\hline \multirow{2}{*}{ Perlakuan } & \multicolumn{5}{|c|}{ Parameter } \\
\cline { 2 - 6 } & Suhu $\left({ }^{\mathbf{0}} \mathbf{C}\right)$ & $\mathbf{p H}$ & $\mathbf{D O}(\mathbf{m g} / \mathbf{L})$ & TAN $(\mathbf{m g} / \mathbf{L})$ & $($ Nitrit $(\mathbf{m g} / \mathbf{L})$ \\
\hline A & $29,8-30,8$ & $7,44-8,11$ & $3,5-5,7$ & $0,0016-0,4906$ & $0.0012-0.5329$ \\
B & $29,8-30,8$ & $7,51-8,1$ & $3,9-5.9$ & $0,0005-0,6597$ & $0,0005-0,4812$ \\
C & $29,8-30,8$ & $7,44-8,05$ & $3,1-5,9$ & $0,0022-0,9433$ & $0,0019-0,5318$ \\
D & $29.9-30.8$ & $7,45-8,02$ & $3,53-5,8$ & $0,0007-0,9546$ & $0,0024-0,5312$ \\
E & $29,9-30,8$ & $7,35-8$ & $3,2-5,8$ & $0,0026-0,6129$ & $0,0008-0,5291$ \\
\hline *) Optimal & $28-32$ & $6-8,5$ & $>3$ mg/L & $<1$ & $<1$ \\
*) Sumber & $\begin{array}{c}\text { Sularto } \text { et } \\
\text { al., } 2007\end{array}$ & $\begin{array}{c}\text { Sularto } \text { et } \\
\text { al. } 2007\end{array}$ & $\begin{array}{c}\text { Legendre } \text { et } \\
\text { al., } 2000\end{array}$ & $\begin{array}{c}\text { Sularto } \text { et al., } \\
\text { 2007, Boyd } 1990\end{array}$ & $\begin{array}{c}\text { Sularto } \text { et al., } \\
2007\end{array}$ \\
\hline
\end{tabular}

\section{PEMBAHASAN}

Pada Gambar 1 terlihat bahwa kematian ikan pada semua perlakuan banyak terjadi pada periode minggu pertama. Pada periode ini larva patin berumur 1-7 hari, sehingga masih rentan terhadap perubahan kondisi media pemeliharaannya. Larva harus dapat beradaptasi dengan pergerakan air dalam sistem resirkulasi dan juga pakan 
yang diberikan yaitu artemia, terlihat banyak artemia yang tidak termakan oleh larva. Kondisi ini menyebabkan tubuh larva menjadi lemas, terlihat pergerakannya tidak aktif dan akhirnya menyebabkan kematian. Makin tinggi padat penebaran larva, kematian larva makin banyak atau kelangsungan hidup larva makin rendah. Menurut Bennet (1970) dan Stickney (1979) peningkatan padat penebaran ikan yang tinggi akan meningkatkan persaingan dalam memperebutkan makanan, ruang gerak dan oksigen terlarut sehingga kelangsungan hidupnya menurun. Dengan penggunaan sistem resirkulasi maka kandungan oksigen terlarut dalam media pemeliharaan larva relatif stabil.

Pada saat larva berumur 21 - 28 hari, terjadi kematian yang cukup banyak, terutama pada kepadatan yang tinggi (40-80 ekor/L). Kepadatan yang tinggi menyebabkan kompetisi diantara larva makin tinggi untuk mempertahankan kelangsungan hidupnya. Seiring dengan pertumbuhan larva, ukuran tubuhnya menjadi lebih besar, kebutuhan oksigen dan pakan meningkat, tetapi ruang gerak makin kecil atau sempit. Stickney (1979), mengemukakan bahwa semakin tinggi kepadatan ikan semakin banyak masalah yang timbul, seperti serangan penyakit, memburuknya kualitas air serta terjadinya kompetisi dalam mengambil pakan.

Padat penebaran tertinggi menunjukkan pertambahan panjang terendah. Menurut Allen (1974) pada tingkat kepadatan yang terlalu tinggi dapat menyebabkan pemanfaatan pakan dan pertumbuhan individu menurun. Hal ini terlihat dari nafsu makan benih berkurang dan sisa pakan yang menumpuk di dasar bak pada perlakuan kepadatan tertinggi. Apabila dilihat dari hasil analisis sidik ragam terhadap rata-rata pertumbuhan panjang mutlak larva patin hibrid pasupati selama penelitian menunjukkan bahwa perbedaan padat penebaran awal memberikan pengaruh terhadap pertumbuhan panjang mutlak larva patin hibrid pasupati.

Hasil pengukuran suhu air berkisaran antara $29,9^{\circ} \mathrm{C}-30,8^{\circ} \mathrm{C}$. Kisaran ini masih berada dalam batas suhu optimal media pemeliharaan ikan patin pasupati yaitu sekitar $28^{\circ} \mathrm{C}-32^{\circ} \mathrm{C}$ (Sularto et al., 2007). Fluktuasi suhu sangat kecil berkisar antara $1^{\circ} \mathrm{C}$ sehingga tidak mengganggu proses metabolisme ikan. Perubahan suhu melebihi $3-4^{\circ} \mathrm{C}$ akan menyebabkan perubahan metabolisme yang mengakibatkan kejutan suhu, meningkatkan toksisitas kontamin yang terlarut, menurunkan DO, dan kematian pada ikan. Dengan demikian suhu dan fluktuasi suhu pada penelitian ini dalam kisaran yang optimal untuk pertumbuhan ikan patin.

Hasil pengukuran $\mathrm{pH}$ dalam air memiliki kisaran 7,35-8,11 yang masih dalam batas aman untuk pemeliharaan larva patin pasupati yaitu pada kisaran $6-8,5$ (Sularto et al. 2007). Pada budidaya sistem resirkulasi, adanya proses nitrifikasi dapat menyebabkan menurunnya nilai $\mathrm{pH}$ air, karena oksidasi ammonia pada filter biologis merupakan sumber keasaman yang potensial yang dapat menyebabkan air menjadi asam (Boyd, 1990). Selama masa pemeliharaan, nilai $\mathrm{pH}$ yang diperoleh relatif stabil dan berkisar antara7,35 - 8,11. Hal ini diduga karena adanya bongkahan karang pada sistem resirkulasi yang dapat berfungsi sebagai penyangga $\mathrm{pH}$ air ( $\mathrm{pH}$ buffer). Bongkahan karang dapat membantu mempertahankan nilai $\mathrm{pH}$ air karena tersusun atas calcium carbonat. Selama ion karbonat atau bikarbonat tersedia dalam air, maka ion hidrogen $\left(\mathrm{H}^{+}\right)$akan dilepaskan dan $\mathrm{pH}$ tidak akan berubah (Stickney, 1993).

Kelarutan oksigen merupakan faktor pembatas dalam budidaya ikan intensif (Boyd, 1982). Kandungan oksigen terlarut pada penelitian ini berkisar antara 3,1 mg/L 
sampai 5,9 mg/L. Konsentrasi oksigen tersebut masih layak untuk patin pasupati karena konsentrasi oksigen terlarut diatas $3 \mathrm{mg} / \mathrm{L}$ masih termasuk dalam batas toleransi ikan patin (Legendre et al., 2000). Dengan menggunakan sistem resirkulasi, adanya aliran air serta aerasi dapat menambah suplai oksigen sehingga mampu mempertahankan konsentrasi oksigen terlarut masih berada dalam kisaran yang layak untuk kebutuhan ikan patin. Selain itu aliran air juga dapat mengangkut akumulasi produk metabolit ikan. Dalam budidaya ikan dengan sistem air mengalir, air dapat berfungsi sebagai sarana transpor oksigen dan buangan hasil metabolisme ikan (Zonneveld et al., 1991).

Dalam budidaya ikan secara intensif, ammonia seringkali menjadi faktor pembatas karena merupakan zat beracun, nilainya bergantung pada kepadatan ikan serta proses pengelolaan air media pemeliharaan. Untuk mengeliminir bahan-bahan dalam bentuk berbahaya seperti amoniak, adanya filter biologi diharapkan dapat membantu proses penyerapan amoniak oleh bantuan pecahan karang, proses oksidasi amoniak menjadi nitrat. Konsentrasi amoniak dalam air selama penelitian berkisar antara 0,0003mg/l - 0,9433 mg/l. Boyd (1990) meyarankan agar konsentrasi amoniak dalam media pemeliharaan ikan tidak lebih dari $1 \mathrm{mg} / \mathrm{L}$. Kisaran konsentrasi ammonia yang optimal untuk patin pasupati adalah $<1 \mathrm{mg} / \mathrm{l}$ (Sularto et al., 2007). Konsentrasi ammonia secara umum dipengaruhi oleh $\mathrm{pH}$ dan suhu air media. Pada $\mathrm{pH} 7$ atau kurang sebagian besar ammonia akan terionisasi, sehingga yang banyak berada dalam perairan adalah dalam bentuk ion ammonium (Nh4-). Amonium dalam perairan tidak beracun bagi ikan.

Selain itu hasil pengukuran terhadap nitrit selama penelitian berkisar antara $0,0001-0,531$. Hal ini menunjukkan bahwa nitrit yang dihasilkan masih berada pada kisaran normal untuk pertumbuhan ikan patin pasupati. Batas aman nitrit untuk pemeliharaan larva patin pasupati adalah tidak lebih dari $1 \mathrm{mg} / \mathrm{l}$ (Sularto et al., 2007).

\section{SIMPULAN}

Pada padat penebaran awal larva patin hibrid pasupati 20 ekor/L - 100 ekor/L menghasilkan kelangsungan hidup, pertumbuhan panjang mutlak dan pertumbuhan bobot mutlak yang berbeda. Makin tinggi padat penebaran, makin rendah kelangsungan hidup, pertumbuhan panjang mutlak dan pertumbuhan bobot mutlak . Padat penebaran yang optimal bagi produksi larva patin pasupati adalah 40 ekor/liter dengan kelangsungan hidup $66,14 \%$, pertumbuhan panjang mutlak $5,03 \mathrm{~cm}$ dan pertumbuhan bobot mutlak 2,05 gram. Padat penebaran tertinggi (100 ekor/L) masih menghasilkan kelangsungan hidup, pertumbuhan panjang mutlak dan pertumbuhan bobot mutlak yang tidak berbeda dengan padat penebaran 60 ekor/L. Peningkatan padat penebaran mengakibatkan menurunnya parameter kualitas air. Namun, penggunaan sistem resirkulasi dalam penelitian ini masih dapat mempertahankan kualitas air yang masih mendukung untuk kelangsungan hidup dan pertumbuhan patin pasupati. 


\section{DAFTAR PUSTAKA}

Alen, K.O. 1974. Effect of Stocking Density and Water Exchange Rate on Growth and Survival of Chanel Catfish Tetalurus functatus. (Refinesque) in Circular Tanks. Aquaculture, 4: 29-39.

Ariyanto, Didik. Evi Tahapari dan Bambang Gunadi. 2008. Optimasi Padat Penebaran Larva Ikan Patin Siam (Pangasius hypopthalmus) Pada Pemeliharaan Sistem Intensif. Jurnal Perikanan. X(2) : $158-166$.

Bennet, G.W. 1970. Management Of Lakes and Ponds. Second Edition. Van Nostrand Reinhold Company. 375 hlm.

Boyd, C. E. 1982. Water Quality Management for Pond Fish Culture. Elselvier Science Publishing Company. Amsterdam. 319 hlm.

Dahuri. 2010. Meningkatkan Kesejahteraan Masyarakat Perikanan Secara Berkelanjutan. Diakses dari http://dahuri.wordpress.com/2010/02/13/meningkatkan-kesejahteraan masyarakat-perikanan-secara-berkelanjutan/. Pada tanggal 11 Oktober 2014.

Effendie, M.I. 1997. Biologi Perikanan. Yayasan Pustaka Nusatama. 163 hlm

Esti, S. 2010. Pertumbuhan dan Sintasan Benih Ikan Patin Pasupati Pada Tingkat Kepadatan Tebar yang Berbeda. Skripsi. Fakultas Perikanan dan Ilmu kelautan. Unila. Lampung. $64 \mathrm{hlm}$.

Hidayat, Ary. 2007. Produksi Benih Ikan Patin (Pangsionodon hypophtalmus Ukuran 6 cm dengan Kepadatan yang Berbeda Dalam Sistem Resirkulasi. Skripsi. Fakultas Perikanan dan Ilmu kelautan. IPB. Bogor. $26 \mathrm{hlm}$.

Legendre, M., Pouyaud L., J. Slembrouck, R. Gustiano, A.H. Kristanto, J. Subagja, O. Komarudin, Sudarto, and maskur. 2000. Pangasius djambal: A new Candidate Species for Fish Culture in Indonesia. Indonesian Agricultural Research \& Development Journal, 22 (1): 1 - 14.

Losordo, T.M. 1988. Recirculation Aquaculture Production System: The Status and Future. Aquaculture, volume 24.

Sularto, Rani Hafsaridewi dan Evi Tahapari. 2007. Petunjuk teknis pembenihan Ikan Patin Pasupati. Loka Riset Pemuliaan Teknologi dan Budidaya perikanan Air Tawar. Departemen Kelautan dan Perikanan. Subang.

Stickney, R.R. 1979. Principles of Warmnwater Aquaculture. John Wiley and Sons. New York.

Zonneveld, N., E.A Huisman and J.H. Boon. 1991. Prinsip-prinsip Budidaya Ikan. PT. Gramedia Pustaka Utama. Jakarta. 